\title{
Yöneticilerin Bakış Açısıyla Meslek Liselerindeki Muhasebe Finansman Alanı Dış Ticaret Ofis Hizmetleri Dalı Eğitimi: İstanbul İli Örneği
}

Bekir KARATAŞ

\section{$\ddot{O Z Z E T}$}

Dış ticaret eğitimi, işletmelerin dış ticaret işlemlerinin yürütülmesi için gerekli dış ticaret bilgi ve becerilerini içeren uygulamalara dayanır. Türkiye'de diş ticaret eğitiminin temeli meslek liselerinde atılmaktadır. Bu çalışmanın amacl; Meslek liselerinde muhasebe finansman alanı, dlş ticaret ofis hizmetleri dalında verilen diş ticaret eğitimini inceleyerek, ögrencilerin aldıkları eğitimin dış ticaretle uğraşan işletmelere uygunluğunu, yöneticilerin bakış açısından değerlendirmektir. Ankete katılanların çoğunluğunu; 31-50 yaş aralığında, erkek, lisans mezunu, 11-15 yıl arası mesleki tecrübeye sahip, Dış ticaret sorumlusu/Şef unvanlı kişiler oluşturmuştur. Çalışmada, Istanbul'daki meslek liselerinde verilen dış ticaret ofis hizmetleri dall eğitiminin, az da olsa yeterli olduğu, eğitim faaliyetlerinde meslek mensup ve örgütlerinin de eğitime dahil edilmesi ve fikirlerinin alınması gerektiği sonucuna ulaşılmiştır.

Anahtar Kelimeler: Muhasebe, Dış Ticaret Eğitimi, Dış Ticaret Ofis Hizmetleri,

Meslek Liseleri

JEL Sinıflandırması: M41, I20.

Accounting and Finance Field Foreign Trade Office Services Branch Education in Vocational High Schools from the Perspective of Managers: Istanbul Case

\section{ABSTRACT}

Foreign trade education is based on the knowledge and skills required for the execution of foreign trade transactions at enterprises. The basics of the foreign trade education begin at the vocational schools in Turkey. The aim of this study is to evaluate the sufficiency of the education that students receive in the accounting and finance, and foreign trade office services field at the vocational schools accordingly with the companies dealing with foreign trade from the managers' point of view. The majority of the respondents; Between the ages of 31-50, male, undergraduate degree, 11-15 years of professional experience, Foreign Trade Responsible/Chief. The findings of this study indicate that the education of foreign trade office services at vocational high schools in Istanbul is barely enough and profesional organizations should be included in the educational activities and views of professionals' should be considered.

Keywords: Accounting, Foreign Trade Education, Foreign Trade Office Services, Vocational Schools.

Jel Classification: M41, I20.

- Bekir Karataş, Sakarya Üniversitesi, Sosyal Bilimler Enstitüsü, İşletme ABD, Muhasebe ve Finansman Bilim Dalı, Doktora Öğrencisi, bekir.karatas@ogr.sakarya.edu.tr 


\section{GíRiş}

Dünyadaki küreselleşme eğilimleri dış ticaretin önemini son yıllarda daha da artırmıştır. Bu nedenle de ülkelerin milli gelirini ve refahını artması açısından dış ticaret önemli bir yere sahiptir. Ülkenin dış ticaretin aksamadan işleyebilmesi için temel dış ticaret bilgilerinin bu sektörde çalışanlar ve çalışacaklar tarafından bilinmesi büyük önem taşımaktadır. Aksi taktirde telafisi güç hatalarla karşılaşılması söz konusu olabilir .

Dış ticaretin başarısı ülkedeki nitelikli insan gücüyle yakından ilgilidir. Nitelikli insan gücü yetiştirebilmenin yolu da eğitimden geçmektedir. Günümüzde ülkemizin dış ticaret hacminin ve işletme sayılarının artması sebebiyle, işletmelerin bu konuda eğitim almış daha çok personele ihtiyacı olduğu bir gerçektir. Dış ticaret alanında personel olarak istihdam edilen öğrencileri yetiştiren mesleki ve teknik liselerin dış ticaret ofis hizmetleri dalı eğitimi daha da önem kazanmaktadır. Ülkemizde orta öğretim düzeyinde dış ticaret ofis hizmetleri eğitiminin verildiği okullar meslek liseleridir. Meslek liselerinde 4 yıl süresince alınan teorik eğitim, son sınıfta işletmelerdeki beceri eğitimi ile birleşip pratiğe dönüşmektedir.

$\mathrm{Bu}$ çalışmada, muhasebe ve finansman alanında yer alan dış ticaret ofis hizmetleri dalı öğrencilerinin aldıkları eğitimin, dış ticaret işlerine uygunluğunun yöneticilerin bakış açısıyla tespit etmek amaçlanmıştır. Uygunluğun tespiti İstanbul ilinde çeşitli işletmelerde yöneticilik yapan kişilerin görüşleri doğrultusunda incelenmiştir. İstanbul'daki işletme yöneticilerinin meslek liselerinde verilen diş ticaret ofis hizmetleri dalı eğitimi hakkındaki görüşleri konu üzerindeki 20 adet anket sorusuyla elde edilmiştir. Çalışmanın ikinci bölümü ise meslek eğitimi ve önemi hakkındadır.

\section{MESLEKİ EĞİTIM VE ÖNEMI}

Mesleki eğitim bir ülkenin kalkınması açısından büyük önem taşımaktadır. Bu nedenle mesleki eğitim sistemini etkin ve verimli şekilde düzenlemiş ülkeler iş dünyasının gereksinim duyduğu elmanı karşılayabilmekte, mal ve hizmet üretim sürecini güçlendirmektedir.

İş gücüne bilgi ve beceri kazandırılmasında önemli bir role sahip olan eğitimin ekonomik gelişmelere katkısı da son derece önemlidir (İçli, 2001: 67). Eğitim farklı şekillerde tanımlanmıştır; Eğitim: bireyi geliştirdiği diğer taraftan ülkenin bilimsel, ekonomik, sosyal ve kültürel kalkınmasını sağladığı için önemlidir ve değeri çok iyi algılanmalıdır (Bowen, 1980). Bir başka deyişle eğitim; genel olarak bireyin yaşadığı toplumda yeteneğini, tutumlarını ve olumlu değerdeki diğer davranış biçimlerini geliştirdiği süreçler toplamı olarak tanımlanmaktadır (Tezcan, 1996:3). Daha geniş anlamıyla eğitim: "Çocuklara, ergenlere ve yetişkinlere kazandırılacak zihinsel ve bedensel yetenekleri edindirmektir. 
Önceden saptanmış amaçlara göre, insanların davranışlarında belli gelişmeler sağlamaya yarayan planlı etkinlikler dizgesidir" (Oğuzhan, 1974: 6). Eğitim seviyesinin yükselmesi işgücünün verimliliğini artırarak maliyet avantajı sağlamakta ve ülkelerin rekabet gücünü olumlu etkileyerek dışa açılmalarını kolaylaştırmaktadır (Çalışkan vd., 2013: 44).

Ülkemizde dış ticaret eğitimi ortaöğretim kurumlarında lise düzeyinde ve yükseköğretim kurumlarında önlisans, lisans ve lisansüstü düzeylerde yapılmaktadır. Eğitim ve öğretim süreçlerinde, her düzeyde nitelikli dış ticaret işlerini yürütecek eleman gereksinimi karşılamak amaçlanmaktadır. Dış ticaret eğitiminin temelleri ülkemizde meslek liselerinde atılmaktadır. Bu yüzden meslek eğitiminin verildiği liselerdeki mesleki eğitiminin önemi bir kez daha ön plana çıkmaktadır.

Çağımız; branşlaşma ve teknolojik ilerleme çağıdır. Bu da ancak kapasiteli, yetenekli, mesleki ve teknik eğitim almış insanlarla sağlanabilir (Erdem, 1999: 241). Mesleki eğitim bir ülkenin kalkınması açısından büyük önem taşımaktadır. Bu nedenle mesleki eğitimi iyi yapılandırabilmiş ülkeler iş dünyasının gereksinim duyduğu elmanı karşılayabilmekte, mal ve hizmet üretim sürecini güçlendirmektedir (Şengel, 2011: 168). Ülkemiz için bu kadar önemli olan mesleki eğitim farklı şekillerde tanımlanmıştır. Meslekî eğitim, "Ülkenin temel ekonomik yapısını kuvvetlendiren ve genişleten, insan kaynağını geliştiren, işsizliği azaltarak üretimin krize girmesini önleyen bir eğitim süreci” olarak da tanımlanmaktadır (Norton, 1985: 9). Mesleki ve teknik eğitim, öğrencileri iyi vatandaş olarak yetiştirmenin yanı sıra esnek bir yapı içinde ilgi ve yetenekleri doğrultusunda ortak bir genel kültür verilerek bir üst öğrenime ve/veya iş hayatına hazırlamayı amaçlamaktadır (M.E.B., 2014: 18). Mesleki eğitim, bireyi sadece "mesleğe hazırlama eğitimi olmayıp" aynı zamanda bireyin tüm olarak gelişimi ve yaşamdaki bütün rolleri en iyi şekilde yerine getirmesi için gerekli nitelikleri kazandırmaya yönelik eğitimdir (Yeşilyaprak, 1996: 68). Dış ticaret, malların ve sermayenin ulusal sınırların dışına akışıyla ilgilidir (Kaya, 2012: 8).

Dış ticaretle ilgili işlemlerinin yapılabilmesi için verilen eğitim dış ticaret eğitimi olarak tanımlanabilir. Dış ticaret ofis hizmetleri dalı eğitiminden beklenen, öğrencilerin dinamik bir alan olan ve çevresinden etkilenen dış ticaret işlerinin gerektirdiği bilgi ve beceriyi edinmesidir. Sektörün beklentilerinin karşılanması için sözü edilen bilgi ve becerilerin bir temeli verilen teorik eğitim ile bir kısmı ise işletmelerdeki beceri eğitimi ile sağlanmaktadır. Dış ticaret eğitiminin kalitesi ülkenin ekonomik yapısını güçlendiren bir rol oynamasından ötürü üstünde durulması gereken bir alan olarak karşımıza çıkmaktadır.

\section{LITERATÜR ARAŞTIRMASI}

Literatüre bakıldığında; (Erdoğan, 1998: 38), Anadolu Dış Ticaret Meslek Liselerinin İhracat Yapan İşletmelerin Personel İhtiyacını Karşılama Düzeyi belirlenmeye çalışılmış ve bazı değerlendirmeler yapılmıştır. Uygulanan öğretim programlarının öğrencileri iş hayatına hazırlamada yetersiz kaldığı, mezunların kısa sürede mesleklerine uygun iş bulamadıkları, 
mezunların asgarî ücret civarında bir ücretle çalışmakta oldukları, bu ücreti mesleklerine ve eğitimlerine uygun bulmadıklarını belirtmiştir.

(Aksakaloğlu, 2013: 138-139), ticaret meslek lisesindeki muhasebe alanında eğitim alan öğrencilerin muhasebe kaydı yapabilme ve belge düzenleme konularında yetersiz oldukları, paket program kullanım noktasında becerikli oldukları, meslek mensuplarından bağımsız hareket edilmemesi gerektiğini ifade etmiştir.

(Akbulut vd., 2014: 86), muhasebe finans alanı öğrencilerini kayıt tutma ve mevzuata konusunda yetersiz bulurken bilgisayar programları konusunda bilgili ve uyumlu olduklarını ifade etmişlerdir.

$\mathrm{Bu}$ çalışmada, işletme yöneticileri ile yüz yüze görüşme yoluyla anket uygulaması yapılmıştır. Yöneticilerin dış ticaret ofis hizmetleri dalı eğitimi hakkındaki görüşlerinin değerlendirilmesi bakımından çalışmanın literatüre katkı sağladığı düşünülmektedir.

\section{ARAŞTIRMANIN AMACI}

$\mathrm{Bu}$ çalışmanın amacı, İstanbul ilindeki meslek liselerinde muhasebe finansman alanı, dış ticaret ofis hizmetleri dalı öğrencilerinin aldıkları eğitimin, dış ticaret işlerine uygunluğunun yöneticilerin bakış açısıyla tespit etmektir. Araştırmamız durum tespitine yönelik bir çalışma olduğundan hipotez kurulmamıştır.

\section{ARAŞTIRMANIN YÖNTEMI}

Araştırmada, daha önce yapılan akademik çalışmalar değerlendirilmiş, bununla birlikte günümüzdeki gelişmeler ve koşullar dikkate alınarak anket formu tasarlanmıştır. Veri toplama aracı olarak kullanılan toplam 25 sorudan oluşan anket, iki bölümden oluşmaktadır. Birinci bölümde görüş bildirenlerin demografik özellikleri, ikinci bölümde ise diş ticaret ofis hizmetleri dalına eğitimine özgü önermeler yer almaktadır.

Anketteki sorular, 1= "Kesinlikle katılmiyorum" 2="Katılmiyorum", 3= "Emin değilim” 4= "Katılıyorum", 5= "Kesinlikle Katılıyorum” şeklinde seçeneklerden oluşan 5'li Likert ölçeğine göre hazırlanmıştır.

\section{ARAŞTIRMANIN EVRENI VE ÖRNEKLEMI}

$\mathrm{Bu}$ çalışmanın evrenini, İstanbul ilinde faaliyet gösteren ve dış ticaret ofis hizmetleri dalı öğrencilerini çalıştıran işletmelerin, farklı pozisyonlarında yöneticilik yapan 387 adet yönetici oluşturmaktadır. Ana kütleden \% 95 güven seviyesinde istatistiksel çıkarsamalar yapmak için 384 adet örneğin yeterli olduğu bilinmektedir (Yazıcıŏglu ve Erdoğan, 2004: 50).

\section{ARAŞTIRMADA KULLANILAN YÖNTEM VE TEKNIK}

Veri toplama aracı olarak anket formu düzenlenmiştir. Anket formları meslek mensupları ile yüz yüze görüşülerek doldurulmuştur. Değerlendirmeye alınan anket sayısı 
387'dir. Ankete verilen cevapların analizinde frekans analizi, ortalama, standart sapma (SS) ve Standart hata $(\mathrm{Sd})$, tek örnek $t$ testi değerleri bulunmuş ve değerlendirmeleri yapılmıştır.

\section{ARAŞTIRMANIN BULGULARI}

Araştırma kapsamında elde edilen betimsel ve istatistiki bulgulara temel teşkil eden veriler 5 demografik ve 20 eğitim ile ilgili toplam 25 adet anket sorusu yardımı ile sağlanmıştır. Ankete katılan kişilerin demografik özellikleri, dış ticaret ofis hizmetleri dalı eğitimiyle ilgili görüşleri grafikler aracılığıyla gösterilmiştir. Anket soruları ve grafikler Ekler bölümünde detaylı şekilde gösterilmiştir. Anket verilerinin güvenilirliği bu araştırmada Cronbach's Alpha istatistiği ile değerlendirilmiştir. (Kılıç, 2016: 48)'e göre Cronbach's Alpha değeri $0,61<\alpha<0,80$ arasında ise ölçek orta güvenilirliktedir. Anketin 20 sorusuna ait olan Cronbach's Alpha değeri ,73 çıkmıştır bu yüzden ölçek için güvenilir denilebilir. Bulgularla ilgili grafikler Ek 2'de sırasıyla gösterilmiştir.

Anketin uygulandığı meslek mensuplarının \% 71,6'sını temsil eden 277 kişi erkek, \%28,4'ünü temsil eden 110 kişi ise bayandır. Görüldüğü gibi ankete katılanların büyük bir çoğunluğunu ( \% 71,6) erkekler oluşturmaktadır (Grafik 1).

Anketin uygulandığ meslek mensuplarının \% 12,1'ini temsil eden 47 kişi 25-30 yaş aralığında, \% 69,8'ini temsil eden 270 kişi 31-50 yaş aralığında ve \% 18' 1'ini temsil eden 70 kişi ise 51 ve üstü yaş aralığındadır. Ankete katılanların büyük çoğunluğu ( \% 69,8 ) 31-50 yaş aralığındadır (Grafik 2).

İstanbul ilinde faaliyet gösteren dış ticaret işlemleriyle uğraşan meslek mensuplarının \% 20,4'ünü temsil eden 79 kişi ön lisans mezunu, \% 77,5'ini temsil eden 300 kişi lisans mezunu, \% 2,1'ini temsil eden 8 kişi işi lisans üstü programlardan mezundur. Sektördeki meslek mensuplarının büyük çoğunluğu $(\% 77,5)$ lisans mezunudur (Grafik 3).

Ankete katılan meslek mensuplarının \% 15'ini temsil eden 58 kişinin mesleki tecrübeleri $\quad 1-5$ yıl, $\%$ 10,9'unu temsil eden 42 kişinin mesleki tecrübesi $6-10$ yıl, \% 31,3’ünü temsil eden 121 kişinin tecrübesi 11-15 yıl, \% 26,1'ini temsil eden 101 kişinin tecrübesi 16-20 y1l ve \% 16,8'ini temsil eden 65 kişinin mesleki tecrübesi ise 21 yıl ve daha fazladır. Verilerden elde edilen sonuçlara göre katılanların yaklaşık \% 74,2'sinin tecrübesi 11 y1l ve daha fazladir (Grafik 4).

Ankete katılan bireylerin \% 28,4'ini temsil eden 110 kişi ithalat/ihracat müdürü, \% 47,8'ini temsil eden 185 kişi dış ticaret sorumlusu/şef, \% 14,7'sini temsil eden 57 kişi gümrük müşaviri, \%9'unu temsil eden 35 kişi ise SMMM/YMM'dir. Görüldüğü üzere ankete katılanların büyük bir çoğunluğunu $(\% 47,8)$ dış ticaret sorumlusu/şef pozisyonunda yönetici olarak çalışanlar oluşturmaktadırlar (Grafik 5).

"Meslek liselerindeki uygulamaya yönelik dersleri, meslek mensuplarının vermesi daha uygundur" anket sorusuna; ankete katılan bireylerin \% 4,9'unu temsil eden 19 kişi katılmıyorum, \% 9,3'ünü oluşturan 36 kişi emin değilim, \% 45,5'ini oluşturan 176 kişi 
katılıyorum, \% 40,3'ünü oluşturan 156 kişi ise kesinlikle katılıyorum demişlerdir. Kesinlikle katılmıyorum seçeneği hiç işaretlenmediği için tabloda gösterilmemiştir. Meslek mensupları yüksek bir oranda toplamda $(\% 85,8)$ diş ticareti ilgilendiren uygulamaya yönelik dersleri kendilerinin vermesi gerektiğini düşünmektedirler (Grafik 6).

"Meslek lisesi öğrencilerine, meslek örgütleri tarafindan dış ticaret ile ilgili seminerler verilmeli ve mesleğe adaptasyon să̆lanmalıdır" sorusuna; ankete katılan bireylerin \% 10,1'ini temsil eden 39 kişi katılmıyorum, \% 5,2'lik kesimini temsil eden 20 kişi emin değilim, \% 43,9'unu temsil eden 170 kişi katılıyorum ve \% 40,8'lik kesimi temsil eden 158 kişi ise kesinlikle katılıyorum seçeneğini tercih etmişlerdir. Hiç katılmıyorum seçeneği kimse tarafından tercih edilmemiştir. Sonuçlardan anlaşıldığı üzere ankete katılan bireylerin \% 84,7'lik kısmı, meslek liselerinde dış ticaret eğitimi alan öğrencilere meslek örgütleri tarafından seminerler verilerek mesleğe adaptasyon sağlanması gerektiğini düşünmektedir (Grafik 7).

"Meslek liselerinde verilen diş ticaret ofis eğitiminin denetimini meslek mensuplar yapmalıdır" anket sorusuna ankete katılan meslek mensuplarının \% 14,7'sini temsil eden 57 kişi katılmıyorum, \% 15'lik kısmını temsil eden 58 kişi emin değilim, \% 34,9'unu temsil eden 135 kişi katılıyorum, \% 35,4'lük kısmını temsil eden 137 kişisi ise kesinlikle katıldığını ifade etmişlerdir. Ankete katılan bireylerin \% 70,3'ü meslek liselerinde verilen eğitimin kendileri tarafından denetlenmesi gerektiğini düşünmektedirler (Grafik 8).

"Meslek liselerindeki diş ticaret ofis hizmetleri dalı müfredatlarının hazırlanmasında meslek mensuplarının fikirleri mutlaka alınmalıdı"” anket sorusuna katılanların \% 59,4'ü temsil eden 230 kişi katılıyorum, \% 40,6'sını temsil eden 157 kişi ise kesinlikle katıllyorum demişlerdir. Ankete katılanlardan hiç biri kesinlikle katılmıyorum, katılmıyorum veya emin değilim seçeneğini tercih etmemiştirler. Dış ticaret ofis hizmetleri alanının müfredatı hazırlanırken kendilerine danışılması gerektiğini düşünmektedirler (Grafik 9).

"Meslek liselerindeki eğitimin bir parçası olan staj uygulamasının, meslekte tecrübe kazanabilmek adına, son sinifta ve 1 yll olarak yapılmasl yeterlidir" anket sorusuna katılımcıların \% 4,7'yi temsil eden 18 kişi kesinlikle katılmıyorum, \% 22,5'ini temsil eden 87 kişi katılmıyorum, \% 20,4'ünü temsil eden 79 kişi emin değilim, \% 32,3'lük kısmını temsil eden 125 kişi katılıyorum, \% 20,2'sini temsil eden 78 kişi ise kesinlikle katılıyorum demiştir. Stajın son sınıfta ve 1 yıl olarak yapılmasını ankete katılanların \% 52,5'lik kısmı yeterli görmektedir (Grafik 10).

"Meslek liselerindeki öğretim programları, öğrencilerin staj yapacă̆l dış ticaret işletmelerinin uygulamaları ile örtüşür" anket sorusuna katılımcıların 25,1'i temsil eden 97 kişi katılmıyorum, \% 50,4'ünü temsil eden 195 kişi emin değilim, \% 19,6'sını temsil eden 76 kişi katılıyorum, \% 4,9'unu temsil eden 19 kişisi ise kesinlikle katılıyorum demişlerdir. Ankete katılanlardan hiç biri kesinlikle katılmıyorum seçeneğini tercih etmemiştir. 
Katılanların \% 50,4'ü meslek liselerindeki öğretim programlarının, dış ticaret işletmelerindeki uygulamalarla örtüşüp örtüşmediği konusunda emin değildirler (Grafik 11).

"Meslek liselerinde dış ticaret ofis hizmetleri dalındaki ögrenciler, aldıkları eğitim ile mevzuata hakimdirler" anket sorusuna katılımcıların \% 59,7'lik kısmını temsil eden 231 kişi katılmıyorum, \% 20,4'ünü temsil eden 79kişi emin değilim, \% 15'ini temsil eden 58 kişi katılıyorum, \% 4,9'unu temsil eden 19 kişisi ise kesinlikle katılıyorum diyerek görüşlerini bildirmişlerdir. Katılanlardan hiç biri kesinlikle katılmıyorum seçeneğini tercih etmemiştir. Verilere göre dış ticaret ofis hizmetleri dalındaki öğrencilerinin \% 59,7'lik bir oranla, dış ticaret mevzuatına hakim olmadıkları ankete katılanlar tarafından belirtilmiştir (Grafik 12).

"Haftada üç gün olan staj çalışma günü artırılmalıdır" anket sorusuna katılımcıların \%2,8'lik kısmını temsil eden 11 kişi kesinlikle katılmıyorum, \% 18,3'lük kısmını temsil eden 71 kişi katılmıyorum, \% 28,4'lük kısmını temsil eden 110 kişi emin değilim, \% 40,6'lık kısmını temsil eden 157 kişi katılıyorum, \% 9,8'lik kısmını temsil eden 38 kişisi ise kesinlikle katılıyorum demişlerdir. Ankete katılanlar staj gün sayısının haftada 3 günden daha çok olması gerektiğini \%50,4 oranında düşünmektedirler (Grafik 13).

"Meslek liselerinde diş ticaret ofis hizmetleri dalındaki öğrenciler dış ticaret işlemleri dersinde okutulan ve diş ticarette kullanılan belgeleri düzenleyebilir" anket sorusuna katılımciların

\% 5,2'lik kısmını temsil eden 20 kişi kesinlikle katılmıyorum, \% 20,4'lük kısmını temsil eden 79 kişi katılmıyorum, \% 35,9'luk kısmını temsil eden 139 kişi emin değilim, \% 38,5'lik kısmını temsil eden 149 kişisi ise katılıyorum seçeneğini tercih etmiştir. Ankete katılanlardan hiç biri kesinlikle katıllyorum seçeneğini tercih etmemiştir. Ankete katılanların \% 38,5'luk kesimi diş ticarette kullanılan belgeleri işyerlerinde düzenleyebileceğini düşünürken, \% 35,9'luk bir kesim ise öğrencilerin belgeleri düzenleyebilecekleri konusunda emin olamamıştır (Grafik 14).

"İhracat ve Ithalat firmalarında siparişlerin alınması, sipariş formlarl ve proforma faturaların hazırlanması, ürünlerin nakliyesi, gümrük işlemleri ve ürün bedellerinin tahsilatı gibi işlemleri yapabilir" anket sorusuna, ankete katılanların \%10,1'lik kısmını temsil eden 39 kişi kesinlikle katılmıyorum, \% 25,3'lük kısmını temsil eden 98 kişi katılıyorum, \% 49,9'luk kısmını temsil eden 193 kişi emin değilim, \% 14,7'lik kısmını temsil eden 57 kişisi ise katılıyorum demiştirler. Ankete katılanlardan hiç biri kesinlikle katılıyorum seçeneğini tercih etmemiştir. Ankete katılanlar büyük oranda ihracat ve ithalat firmalarındaki belirtilen işlemleri \% 49,9 oranında öğrencilerin yapılabileceğinden emin olmadıklarını belirtmişlerdir (Grafik 15).

"Dlş ticaret ofis hizmetleri bölümlerinden mezun olan öğrenciler, öğretim süreci sırasında gördükleri kambiyo senetlerini (bono, poliçe ve çek) çalıştıkları işyerlerinde rahatlıkla düzenleyebilirler" anket sorusuna katılımciların \% 7,5'lik kısmını temsil eden 29 kişi kesinlikle katılmıyorum, \% 15'lik kısmı temsil eden 44 kişi katılmıyorum, \% 31,5'lik 
kısmını temsil eden 122 kişi emin değilim, \% 49,6'lık kısmını temsil eden 192 kişisi ise katılıyorum demiştir. Ankete katılanlardan hiç biri kesinlikle katılıyorum seçeneğini tercih etmemiştir. \% 49,6’lık bir oranda katılımcılar dış ticaret alanından mezun olan öğrencilerin alanla ilgili belgeleri düzenleyebileceklerini düşünmektedirler (Grafik 16).

"Dış ticaret ofis hizmetleri alanından mezun olan ögrenci, dış ticarette teslim ve ödeme şekilleri işlemlerini yapabilir" anket sorusuna katılımcılardan \% 10,1'lik kısmını temsil eden 39 kişi kesinlikle katılmıyorum, \% 20,4'lük kısmını temsil eden 79 kişi katılmıyorum, \% 50,1'ini temsil eden 194 kişi emin değilim, \% 19,4'luk kısmını temsil eden 75 kişisi ise katılıyorum seçeneğini tercih etmişlerdir. Ankete katılanlardan hiç biri kesinlikle katılıyorum seçeneğini tercih etmemiştir. Ankete katılanların \% 50,1'lik kısmı dış ticaret alanından mezun olan öğrencilerin, dış ticarette teslim ve ödeme şekilleri işlemlerini yapabileceklerinden emin değildirler (Grafik 17).

"Dış ticaret ofis hizmetleri alanından alınan eğitim ile ögrenciler, herhangi bir dış ticaret firmasinın ithalat ve ihracatına ilişkin, muhasebe işlemlerini ve kayıtlarını yapabilirler" anket sorusuna katılımcılardan, \% 7,8'lik kısmını temsil eden 30 kişi kesinlikle katılmıyorum, \%17,2'lik kısmını temsil eden 68 kişi katılmıyorum, \% 38'i temsil eden 147 kişi emin değilim, \% 36,7'sini temsil eden 142 kişisi ise katılıyorum seçeneğini tercih etmiştir. Ankete katılanlardan hiç biri kesinlikle katılıyorum seçeneğini tercih etmemiştir. Ankete katılanların çoğunluğu \% 38 oranında dış ticaret ofis hizmetleri alanından alınan eğitim ile öğrencilerin, herhangi bir dış ticaret firmasının ithalat ve ihracatına ilişkin, muhasebe işlemlerini ve kayıtlarını yapabileceklerinden emin olmadıklarını belirtmiştirler (Grafik 18).

"Dış ticaret ofis hizmetleri dalından mezun olan öğrenci, dış ticaret işletmelerini sinıflandırarak kullanılan belgeleri ilgili defterlere kaydedebilir" anket sorusuna katılımcılardan \%6,2'lik kısmını temsil eden 24 kişi kesinlikle katılmıyorum, \% 11,6'lık kısmını temsil eden 45 kişi katılmıyorum, \% 30'unu temsil eden 116 kişi emin değilim, \% 37,7'sini temsil eden 146 kişi katılıyorum, \% 14,5'lik kısmını oluşturan 56 kişisi ise kesinlikle katılıyorum seçeneğini tercih etmiştir. Ankete katılanlar \% 52,2 oranında dış ticaret ofis hizmetleri alanından mezun dış ticaret alanı öğrencilerinin ilgili belgeleri defterlere kayıt yapabileceklerini düşünmektedirler (Grafik 19).

"Meslek liselerinde verilen ögrretim ile, ögrenciler şirket türleri ve özelliklerine göre muhasebe kayıtlarını yapabilirler" anket sorusuna katılımcıların \% 4,9'luk kısmını temsil eden 19 kişi kesinlikle katılmıyorum, \% 30,5'lik kısmını temsil eden 118 kişi katılmıyorum, \% 40,1'lik kısmını temsil eden 155 kişi emin değilim, \% 24,5'lik kısmını teşkil eden 95 kişisi ise katılıyorum demiştir. Ankete katılanlardan hiç biri kesinlikle katıllyorum seçeneğini tercih etmemiştir. Ankete katılanların \% 40,1'i dış ticaret ve ofis öğrencilerinin, dış ticaret işlemlerinin muhasebe kayıtlarını yapabilecekleri konusunda emin olmadıklarını belirterek en yüksek oranlı görüşü ifade etmişlerdir (Grafik 20). 
"Meslek liselerinde okutulan Muhasebe I ve Muhasebe II derslerinde ögretilen bilgilerle ögrenciler işletmelere özgü ticari belgeleri, ticari defterleri ve beyannameleri, staj yerlerinde düzenleyebilir" anket sorusuna katılımcıların \%15'lik kısmını temsil eden 58 kişi kesinlikle katılmıyorum, \% 20,4'ünü temsil eden 79 kişi katılmıyorum, \% 25,1'lik kısmını temsil eden 97 kişi emin değilim, \% 39,5'ini temsil eden 153 kişisi ise katılıyorum seçeneğini tercih etmiştir. Ankete katılanlar kesinlikle katılıyorum seçeneğini tercih etmemiştir. Ankete katılanların \% 39,5'lik bir kısmı, staj yapan öğrencilerin Muhasebe I ve Muhasebe II derslerinde gördükleri belgeleri, ticari defter ve beyannameleri stajda düzenleyebilecekleri fikrine katılmaktadırlar (Grafik 21).

"Meslek liselerinde herhangi bir bilgisayar programı ögrenen öğrenci, staj uygulamasında farklı bir programa kolaylıkla uyum sağlar” anket sorusuna katılımcıların \% 14,7'lik kısmını temsil eden 57 kişi katılmıyorum, \% 25,1'lik kısmını temsil eden 91 kişi emin değilim, \% 45,2'sini temsil eden 175 kişi katılıyorum, \% 15'lik kısmını temsil eden 58 kişisi ise kesinlikle katılıyorum seçeneğini tercih etmiştir. Ankete katılanlardan hiç biri kesinlikle katılmıyorum seçeneğini tercih etmemiştir. Ankete katılanların \%60,2'si meslek liselerinde herhangi bir bilgisayar programı öğrenen öğrencilerin, staj uygulamasında farklı bir programa kolaylıkla uyum sağladığını belirtmişlerdir (Grafik 22).

"Meslek lisesi ögrencileri, staj yaptıkları işyerlerinde, muhasebe işlerini, dış ticaret belgelerini bilgisayar kullanarak düzenleyebilir" anket sorusuna katılımcıların \% 15,2'lik kısmını temsil eden 59 kişi katılmıyorum, \% 30,7’lik kısmını temsil eden 119 kişi emin değilim, \% 54'lük kısmını temsil eden 209 kişisi ise katılıyorum seçeneğini tercih etmişlerdir. Ankete katılanlardan hiç biri kesinlikle katılmıyorum/katılıyorum seçeneklerini tercih etmemiştir. Ankete katılanların \% 54'ü meslek lisesi öğrencilerinin, staj yaptıkları işyerlerinde, muhasebe fişlerini, diş ticaret belgelerini bilgisayar kullanarak düzenleyebileceğini belirtmiştir (Grafik 23).

"Meslek liselerinde okutulan bilgisayarda ofis programlart dersi ve bilgisayarda klavye dersleri dış ticaret işlerine uygundur" anket sorusuna katılımcıların \% 15,2'lik kısmını temsil eden 59 kişi katılmıyorum, \% 20,2'lik kısmını temsil eden 78 kişi emin değilim, \% 44,7'lik kısmını temsil eden 173 kişisi ise katılıyorum, \% 19,9'unu temsil eden 77 kişi ise kesinlikle katılıyorum seçeneğini tercih etmişlerdir. Ankete katılanlardan kesinlikle katılmıyorum seçeneğini tercih eden olmamıştır. Ankete katılanların \% 64,6'sı meslek liselerinde okutulan bilgisayarda ofis programları ve bilgisayarda klavye derslerinin, dış ticaret işlerine uygun olduğunu düşünmektedir (Grafik 24).

"Dış ticaret ofis hizmetleri mezunları, kendi alanlarında iş bulma konusunda daha avantajlıdırlar" anket sorusuna katılımcıların \% 10,1'lik kısmını temsil eden 39 kişi katılmıyorum, \% 10,3'lük kısmını temsil eden 40 kişi emin değilim, \% 49,9'luk kısmını temsil eden 193 kişisi ise katıllyorum, \% 29,7'ini temsil eden 115 kişi ise kesinlikle katılıyorum seçeneğini tercih etmişlerdir. Ankete katılanlardan kesinlikle katılmıyorum 
seçeneğini tercih eden olmamıştır. Ankete katılanların \% 79,6'sı dış ticaret ofis hizmetleri mezunlarının, kendi alanlarında iş bulma konusunda daha avantajlı olduklarını düşünmektedirler (Grafik 25).

Anket 20 soru olup geniş hali Ek 1'de sunulmuştur. Sorulara verilen cevapların ortalamaları ve ortalamalar referans alınarak tek örnek $t$-testi sonuçları Tablo 1'de verilmiştir.

Tablo 1. Yöneticilerin Bakış Açısıyla Dış Ticaret Ofis Hizmetleri Dalı Eğitimi

\begin{tabular}{|c|c|c|c|c|c|c|c|}
\hline \multicolumn{2}{|r|}{ Sorular } & \multirow{2}{*}{$\begin{array}{l}\text { Ort. } \\
4,21 \\
\end{array}$} & \multirow{2}{*}{$\begin{array}{c}* \text { * SS } \\
, 806\end{array}$} & \multirow{2}{*}{$\begin{array}{c}* \text { Sd } \\
, 041\end{array}$} & \multirow{2}{*}{$\begin{array}{c}* t \\
29,59 \\
\end{array}$} & \multirow{2}{*}{\begin{tabular}{|r|} 
* Sig. \\
, 000 \\
\end{tabular}} & \multirow{2}{*}{$\begin{array}{c}\text { Sonuç } \\
\text { Olumlu }\end{array}$} \\
\hline 1 & Uygulama derslerini meslek mensupları vermeli. & & & & & & \\
\hline 2 & Meslek örgütleri tarafindan seminerler verilmeli. & 4,16 & ,917 & 047 & 24,77 & ,000 & Olumlu \\
\hline 3 & $\begin{array}{l}\text { Dış ticaret eğitimi denetimini meslek mensupları } \\
\text { yapmalı. }\end{array}$ & 3,91 & 1,043 &, 053 & 17,16 &, 000 & Olumlu \\
\hline 4 & $\begin{array}{l}\text { Müfredatlarının hazırlanmasında meslek mensuplarının } \\
\text { fikirleri alınmalı. }\end{array}$ & 4,41 & ,492 &, 025 & 56,24 &, 000 & Olumlu \\
\hline 5 & Stajın son sınıfta ve 1 yıl olması yeterli & 3,41 & 1,173 & 060 & 6,84 & ,000 & Olumlu \\
\hline 6 & Öğretim Prg. işletmelerinin uygulamaları ile örtüşür. & 3,04 & ,802 & 041 & 1,08 & ,282 & Emin Değil \\
\hline 7 & Öğrenciler, aldıkları eğitim ile mevzuata hakimdirler. & 2,65 & ,908 & 046 & $-7,56$ & 000 & Olumsuz \\
\hline 8 & Haftada üç gün olan staj çalışma günü artırılmalıdır. & 3,36 & ,983 & 050 & 7,24 & 000 & Olumlu \\
\hline 9 & $\begin{array}{l}\text { Öğrenciler, dış ticaret isslemleri dersinde okutulan ve } \\
\text { dış ticarette kullanılan belgeleri düzenleyebilir. }\end{array}$ & 3,08 & 890 &, 045 & 1,71 & 087 & Emin Değil \\
\hline 10 & $\begin{array}{l}\text { Öğrenciler proforma fatura düzenler, sipariş, nakliye } \\
\text { ve gümrük işlemlerini yapabilir }\end{array}$ & 2,69 & 843 &, 043 & $-7,17$ &, 000 & Olumsuz \\
\hline 11 & Öğrenciler Kambiyo senetlerini düzenleyebilir & 3,23 & ,926 & 047 & 4,94 & ,000 & Olumlu \\
\hline 12 & $\begin{array}{l}\text { Mezun Öğgr., D1ş ticarette teslim ve ödeme şekilleri } \\
\text { işlemlerini yapabilir. }\end{array}$ & 2,79 &, 871 &, 044 & $-4,79$ & ,000 & Olumsuz \\
\hline 13 & $\begin{array}{l}\text { Öğrenciler, İthalat ve ihracatla ilgili muhasebe işlem ve } \\
\text { kayttlarını yapabilirler. }\end{array}$ & 3,04 & 0,92 & 0,05 & 0,77 & ,442 & Emin Değil \\
\hline 14 & $\begin{array}{l}\text { Dış ticaret mezunları, dış ticaret işletmelerini } \\
\text { sınıflandırır, belgeleri defterlere kaydedebilir. }\end{array}$ & 3,43 & 1,068 &, 054 & 7,85 & ,000 & Olumlu \\
\hline 15 & $\begin{array}{l}\text { Öğrenciler, Sirket tür ve özelliklerine göre muh. } \\
\text { kaydı yapabilir. }\end{array}$ & 2,84 &, 851 &, 043 & $-3,64$ & ,000 & Olumsuz \\
\hline 16 & $\begin{array}{l}\text { Muhasebe I-II derslerinde öğretilen bilgilerle } \\
\text { öğrenciler, defter ve beyannameleri düzenleyebilir. }\end{array}$ & 2,89 & 1,091 &, 055 & $-1,96$ &, 051 & Emin Değil \\
\hline 17 & $\begin{array}{l}\text { Öğr. İsletmedeki farklı bir bilgisayar programına } \\
\text { kolaylıkla uyum sağlar. }\end{array}$ & 3,60 & ,914 &, 046 & 13,01 & ,000 & Olumlu \\
\hline 18 & $\begin{array}{l}\text { Öğr., muhasebe fişlerini, dış ticaret belg. bilgisayar } \\
\text { kullanarak düzenleyebilir. }\end{array}$ & 3,39 & ,737 &, 037 & 10,34 & ,000 & Olumlu \\
\hline 19 & $\begin{array}{l}\text { Öğr. Okulda aldıkları bilg. ofis prg. dersi ve bilg. } \\
\text { klavye dersleri dış ticaret işlerine uygundur. }\end{array}$ & 3,69 & ,958 &, 049 & 14,22 & ,000 & Olumlu \\
\hline 20 & Öğrenciler kendi alanlarında iş bulmada avantajlıdır. & 3,99 & 898 & 046 & 21,75 & 000 & Olumlu \\
\hline & $\begin{array}{l}\text { Tabloda SS (standart hata), Sd (Standart sapma) } \\
\text { Tablonun daha öz olması için anket soruları kıš }\end{array}$ & der. & 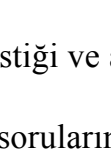 & & & & \\
\hline
\end{tabular}


Meslek mensuplarının anketteki konulara ait 5'li Likert ölçeğinde alınmış görüşlerin birim temelli ortalamaları, ortalama (Ort.) sütunundadır. Bu ortalamalar için emin olmama noktası olan 3'den farklı bir görüşe sahip olduklarının istatistiksel anlamlılık incelenmesinde tek örnek $t$ testi kullanılmıştır. Görüşü alınan yönetici sayısı 30'un üzerinde olduğundan verilerin normal dağıldığı kabul edilmiş Tablo 1'deki tüm $t$ testi sonuçları parametrik testlerden olan (3 referans alınarak hesaplanan) $t$ testi istatistikleridir.

Tek örnek t testlerinin 0,05 referans alınarak bakıldığginda, anlamlılığı 0,05 'ten küçük olan 16 soruda, bireylerin olumlu veya olumsuz yönlü fikre sahip olduğu, Anlamlılığ 0,05'ten büyük olan 4 soru için, bireylerin açık bir fikrinin olmadığı, emin olmadıkları görülmektedir. Yukarıdaki tabloda anlamlılık (sig.) sütunundaki değerlere bakılacak olursa; 4 değerin 0,05 'ten büyük, 16 değerin ise 0,05 'ten küçük olduğu seklinde bir sonuç elde ediyoruz. Yani 6, 9, 13 ve 16. Sorular arasında istatistiksel olarak anlamlı bir farklılık yoktur. Diğer sorularda ise, yine istatistiksel olarak anlamlı bir fark olduğu şeklinde yorum yapılabilir. Yöneticilerin genel görüşlerine bakıldığında, İstanbul ilindeki meslek liselerinde muhasebe finansman alanı, diş ticaret ofis hizmetleri dalı öğrencilerinin aldıkları eğitimin, dış ticaret işlerine uygunluğu konusunda 12 konuda olumlu görüş, 4 konuda olumsuz görüş, 4 konuda ise emin değilim görüşü söz konusudur. Tüm soruların cevaplarının ortalaması 3,39 olup 0,05 düzeyinde istatistiksel olarak 3'den farklılığının anlamlı olduğu görülmektedir. Bu durumda, meslek mensuplarının burada bahsi geçen 20 konuya az da olsa olumlu baktıkları görülmektedir.

Tablodaki sorular incelendiğinde, ilk 4 konu öneri niteliğinde iken, son 16 soru ise meslek liselerindeki dış ticaret ofis hizmetleri dalı eğitiminin uygun olup olmadığına yöneliktir. Son 16 sorunun ortalaması 3,20 olup, İstanbul ilindeki meslek liselerinde verilen dış ticaret ofis hizmetleri eğitiminin yeterliliğinin yöneticilerin bakış açısıyla az da olsa olumlu olduğu söylenebilir. İlk 4 sorudaki yöneticilerin eğitimde etkin olarak görev almasını ifade eden önerilerin ortalaması ise 4,17 olup, yöneticiler tarafindan oldukça olumlu karş1landığı görülmüştür.

\section{SONUÇ}

Ülkemizde dış ticaret eğitiminin temelleri meslek liselerinde atılmaktadır. Meslek liselerinde dördüncü sınıfa gelen öğrenciler aldıkları eğitimin pratiğini yapmak için işletmelerde beceri eğitimine giderler. Dış ticaret ofis hizmetleri dalı öğrencileri çeşitli diş ticaret şirketlerinde, gümrük müşavirliği firmalarında, S.M.M.M./Y.M.M bürolarında, kamu kurumlarının ilgili bölümlerinde ve diğer bir çok farklı işletmede istihdam edilmektedir. Çeşitli türdeki işletmelerde farklı pozisyonlarda çalışan yöneticiler, meslek liselerinde verilen eğitim konusunda yanlarına gelen stajyer öğrenciler vasıtasıyla fikir sahibi olabilmektedirler. $\mathrm{Bu}$ bağlamda yanlarında dış ticaret ofis hizmetleri dalı öğrencilerini istihdam eden farklı unvanlardaki 387 yöneticiye, 5'li Likert ölçeğine göre hazırlanmış 20 adet anket sorusu yönlendirilmiş ve aşağıdaki sonuçlara ulaşılmıştır. Bu görüşler, İstanbul'da yanlarında meslek 
lisesi öğrencileri çalıştıran yöneticilere ait olup, yöneticiler ağırlıklı olarak erkek, orta yaşlı, lisans mezunu, dış ticaret sorumlusu/şef, 11-15 yıl arası tecrübeye sahiptirler.

Öğrencilerin genel anlamda mevzuata hakim oldukları, fatura düzenleyebildikleri, sipariş, nakliye ve gümrük işlemlerini yapabildikleri, dış ticarette teslim ve ödeme şekilleri işlemlerini yaptıkları ve şirket tür ve özelliklerine göre muhasebe kaydı yaptıklarını belirten konularda yöneticiler olumsuz görüş bildirmişlerdir. Okul öğretim programlarının işyeri uygulamaları ile örtüşmesi, öğrencilerin dış ticaret belgelerini düzenlemesi, ithalat-ihracatla ilgili muhasebe kayıtlarının yapılması, defter ve beyannamelerin öğrenciler tarafindan düzenlenip düzenlenemeyeceğini belirten konularda yöneticiler emin olmadıklarını belirtmişlerdir.

Yöneticiler işletmelerdeki beceri eğitiminin hali hazırdaki süresini yeterli görmüş, öğrencilerin bilgisayar kullanma ve kullanılan paket programlara uyumları ile ilgili konularda yüksek oranda olumlu görüş belirtmiş̧lerdir. Yöneticiler Özellikle diş ticaret ofis hizmetleri alanı mezunlarının kendi alanlarında iş bulma konusunda avantajı olduğunu yöneticiler tarafından belirtilmiştir. Öneri niteliğinde olan, dış ticaret eğitimine meslek mensup ve örgütlerinin katılması ve fikirlerinin alınması konusunda yöneticiler yüksek oranda olumlu görüş bildirmişlerdir.

Sonuç olarak, yöneticilere göre İstanbul'daki meslek liselerinde verilen diş ticaret ofis hizmetleri dalı eğitiminin, bazı konularda yeterli olmamakla birlikte, genel anlamda az da olsa yeterli olduğu görünmektedir. Dış ticaret ofis hizmetleri dalı öğrencilerinin eğitiminde meslek mensup ve örgütlerinin de eğitime dahil edilmesi ve fikirlerinin alınması gerektiği tespit edilmiştir. 


\section{KAYNAKLAR}

Aksakaloğlu, Hakan (2013), Ticaret Meslek Liselerinde Verilen Muhasebe Eğitiminin Muhasebecilik Mesleğine Uygunluğu: Bursa İli Örneği, Bülent Ecevit Üniversitesi, Sosyal Bilimler Enstitüsü, İşletme Enstitüsü Bilim Dalı, Yüksek Lisans Tezi, Zonguldak.

Akbulut, Halim-Pekkaya, Mehmet-Aksakaloğlu, Hakan (2014), “Meslek Mensuplarının Bakış Açısıyla Ticaret Meslek Liselerindeki Muhasebe Eğitimi”: Bursa İli Üzerine Bir Uygulama, Muhasebe ve Finansman Dergisi, Say1.62, Nisan, ss.73-92.

Bowen, Howard R. (1980), Investment In Learning. San Francisco: Jossey Bass Publishers.

Çalışkan, Şadan- Karabacak, Mustafa-Meçik, Oytun (2013), “Türkiye'de Eğitim-Ekonomik Büyüme İlişkisi: 1923-2011(Kantitatif Bir Yaklaşım)”, Yönetim Bilimleri Dergisi, Cilt 11, Sayı 21, Şubat, ss.25-48.

Erdem, Cemal (1999), 16. Milli Eğitim Şurası: Konuşmalar, Görüşler, Kararlar ve Raporlar, Milli Eğitim Basım Evi, M.E.B., Ankara.

Erdoğan, Mehmet Hacı (1998), Anadolu Dış Ticaret Meslek Liselerinin İhracat Yapan İşletmelerin Personel İhtiyacını Karşılama Düzeyi, Gazi Üniversitesi, Sosyal Bilimler Enstitüsü, Yüksek Lisans Tezi, Ankara.

İçli, Gönül (2001), "Eğitim, İstihdam ve Teknoloji”, Pamukkale Üniversitesi Eğitim Fakültesi Dergisi, Say1 9, Ocak, ss.65-71.

Kaya, Feridun (2012), Dış Ticaret İşlemleri, Anadolu Üniversitesi Yayını, Yayın no: 2526, Eskişehir.

Kılıç, Selim (2016), “Cronbach'ın Alfa Güvenirlik Katsayısı”, Journal Of Mood Disorders, Cilt 6, Say1.1, ss.47-48.

Milli Eğitim Bakanlığı (2014), Türkiye Mesleki ve Teknik Eğitim Strateji Belgesi ve Eylem Planı 2014-2018, M.E.B., Ankara.

Norton, Robert Ellsworth (1985), Develop Local Plans for Vocational Education, Colombus The Ohio State University.

Oğuzhan, Ferhan (1974), Eğitim Terimleri Sözlügü, Tak Yayınları, Ankara.

Şengel, Salim (2011), “Türkiye'de Muhasebe Meslek Elamanı Talebi Üzerine Bir Araştırma”, Muhasebe ve Finansman Dergisi, Say1.50, Nisan, ss.167-180.

Tezcan, Mahmut (1996), Eğitim Sosyolojisi, Feryal Matbaası, Ankara.

Yazıcıoğlu, Yahşi - Erdoğan, Samiye (2004), Spss Uygulamalı Bilimsel Araştırma Yöntemleri, Detay Yayıncılık, Ankara.

Yeşilyaprak, Binnur (1996), Yaşam Odaklı Meslek Eğitimi Yaklaşımı Açısından Mesleki Rehberliğin Yeri ve İşlevi. 21. Yüzyıla Doğru Meslek Yüksekokullarının Yeniden Yapılandırılması Sempozyumu, Çankırı. 


\section{Ek 1 : Anket Formu ve Soruları Tablosu}

\section{Yöneticilerin Bakış Açısıyla Meslek Liselerindeki}

\section{Muhasebe Finansman Alanı Dış Ticaret Ofis Hizmetleri Dalı Eğitimi Anketi}

Değerli yöneticiler,

Bu araştırma, Meslek Liselerinde Muhasebe-finansman alanı, dıș ticaret ve ofis hizmetleri dalında verilen eğitimin diş ticaret işlerine uygunluğunu ölçmeye yöneliktir.

Elde edilen bilgiler yalnızca bilimsel amaçlar için kullanılacaktır.

Gösterdiğiniz ilgi ve katkı için teşekkür ederiz.

Bekir KARATAS

\begin{tabular}{|c|c|}
\hline \multirow{2}{*}{ Cinsiyet } & Kadın \\
\hline & Erkek \\
\hline \multirow{3}{*}{ Yaş } & $25-30$ yaş \\
\hline & 31-50 yaş \\
\hline & 51 ve üstü \\
\hline
\end{tabular}

\begin{tabular}{|l|c|l|}
\hline \multirow{4}{*}{$\begin{array}{l}\text { Mesleki } \\
\text { Tecrübe }\end{array}$} & $1-5$ y1l & \\
\cline { 2 - 3 } & $6-10$ y1l & \\
\cline { 2 - 3 } & $11-15$ y1l & \\
\cline { 2 - 3 } & $16-20$ y1l & \\
\hline & 21 y1l ve üstü & \\
\hline
\end{tabular}

\begin{tabular}{|c|c|c|}
\hline \multirow{4}{*}{ Eğitim } & Lise & \\
\cline { 2 - 3 } & Önlisans & \\
\cline { 2 - 3 } & Lisans & \\
\hline & Lisans üstü & \\
\hline
\end{tabular}

\begin{tabular}{|c|c|l|}
\hline \multirow{4}{*}{ Unvan } & $\begin{array}{c}\text { İthalat/İhracat } \\
\text { Müdürü }\end{array}$ & \\
\cline { 2 - 3 } & $\begin{array}{c}\text { Diş Ticaret } \\
\text { Sorumlusu/Şef }\end{array}$ & \\
\cline { 2 - 3 } & Gümrük Müşaviri & \\
\cline { 2 - 3 } & SMMM/YMM & \\
\hline
\end{tabular}

1 Meslek liselerindeki uygulamaya yönelik dersleri, meslek mensuplarının vermesi daha uygundur.

2 Meslek lisesi öğrencilerine, meslek örgütleri tarafından (Türmob, Gümr. müş.der.) dış ticaret ile ilgili seminerler verilmeli ve mesleğe adaptasyon sağlanmalıdır.

3 Meslek liselerinde verilen dış ticaret ofis eğitiminin denetimini meslek mensupları yapmalıdır.

4 Meslek liselerindeki dış ticaret ofís hizmetleri dalı müfredatlarının hazırlanmasında meslek mensuplarının fikirleri mutlaka alınmalıdır.

5 Meslek liselerindeki eğitimin bir parçası olan staj uygulamasının, meslekte tecrübe kazanabilmek adına, son sinıfta ve 1 yıl olarak yapılması yeterlidir.

6 Meslek liselerindeki öğretim programları, öğrencilerin staj yapacağı dış ticaret işletmelerinin uygulamaları ile örtüşür.

7 Meslek liselerinde dış ticaret ofis hizmetleri dalındaki öğrenciler, aldıkları eğitim ile dış ticaret mevzuatına hakimdirler.

8 Meslek liselerinde haftada üç gün olan staj çalışma günü artırılmalıdır.

9 Meslek liselerinde dış ticaret ofis hizmetleri dalındaki öğrenciler diş ticaret işlemleri dersinde okutulan ve dış ticarette kullanılan belgeleri düzenleyebilir. 
10 Öğrenciler, İhracat ve İthalat firmalarında siparişlerin alınması, sipariş formları ve proforma faturaların hazırlanması, ürünlerin nakliyesi, gümrük işlemleri ve ürün bedellerinin tahsilatı gibi işlemleri yapabilir.

11 D1ş ticaret ofis hizmetleri bölümlerinden mezun olan öğrenciler, öğretim süreci sırasında gördükleri kambiyo senetlerini (bono, poliçe ve çek) çalıştıkları işyerlerinde rahatlıkla düzenleyebilirler.

12

Dış ticaret ofis hizmetleri alanından mezun olan öğrenci, dış ticarette teslim ve ödeme şekilleri işlemlerini yapabilir.

13 Dış ticaret ofis hizmetleri dalında aldıkları eğitim ile öğrenciler, herhangi bir dış ticaret firmasının ithalat ve ihracatına ilişkin, muhasebe işlemlerini ve kayıtlarını yapabilirler.

14 Dış ticaret ofis hizmetleri dalından mezun olan öğrenci, dış ticaret işletmelerini sınıflandırarak kullanılan belgeleri ilgili defterlere kaydedebilir.

15 Meslek liselerinde verilen öğretim ile, öğrenciler şirket tür ve özelliklerine göre muhasebe kayıtlarını yapabilirler.

16 Meslek liselerinde okutulan Muhasebe I ve Muhasebe II derslerinde öğretilen bilgilerle öğrenciler işletmelere özgü ticari belgeleri, ticari defterleri ve beyannameleri, staj yerlerinde düzenleyebilir.

17 Meslek liselerinde herhangi bir bilgisayar programı öğrenen öğrenci, staj uygulamasında farklı bir programa kolaylıkla uyum sağlar.

18 Meslek lisesi öğrencileri, staj yaptıkları işyerlerinde, muhasebe fiş̧lerini, dış ticaret belgelerini bilgisayar kullanarak düzenleyebilir.

19 Meslek liselerinde okutulan bilgisayarda ofis programları dersi ve bilgisayarda klavye dersleri diş ticaret işlerine uygundur.

20 Diş ticaret ofis hizmetleri mezunları kendi dallarında iş bulmada avantajlıdır.

* Anket formu, (Aksakaloğlu, Hakan 2013: 165)'na ait Yüksek Lisans tezi anket sorularının, dış ticaret ofis hizmetleri dalına göre uyarlanması neticesi yeniden oluşturulmuştur. 
Ek 2 : Grafikler
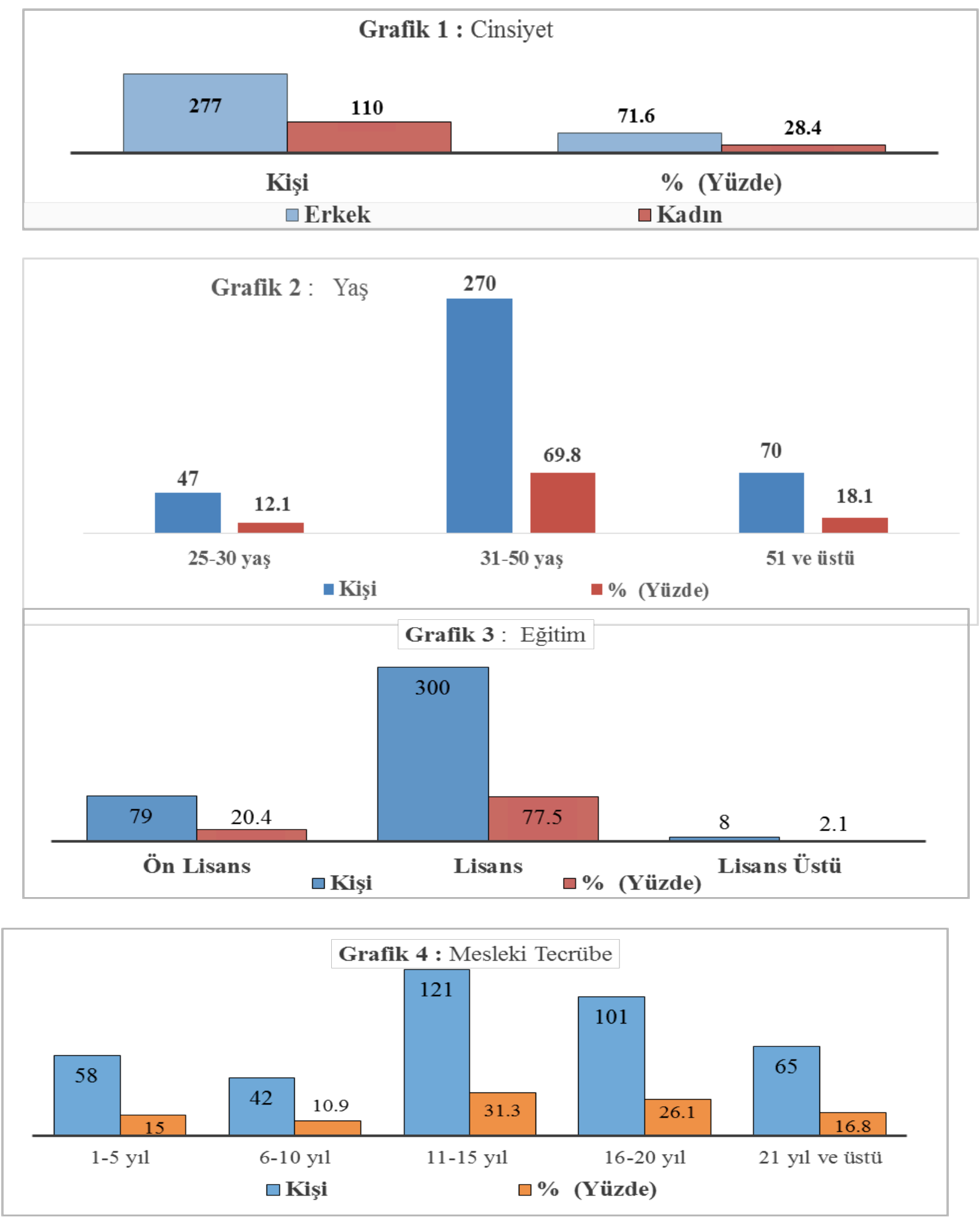

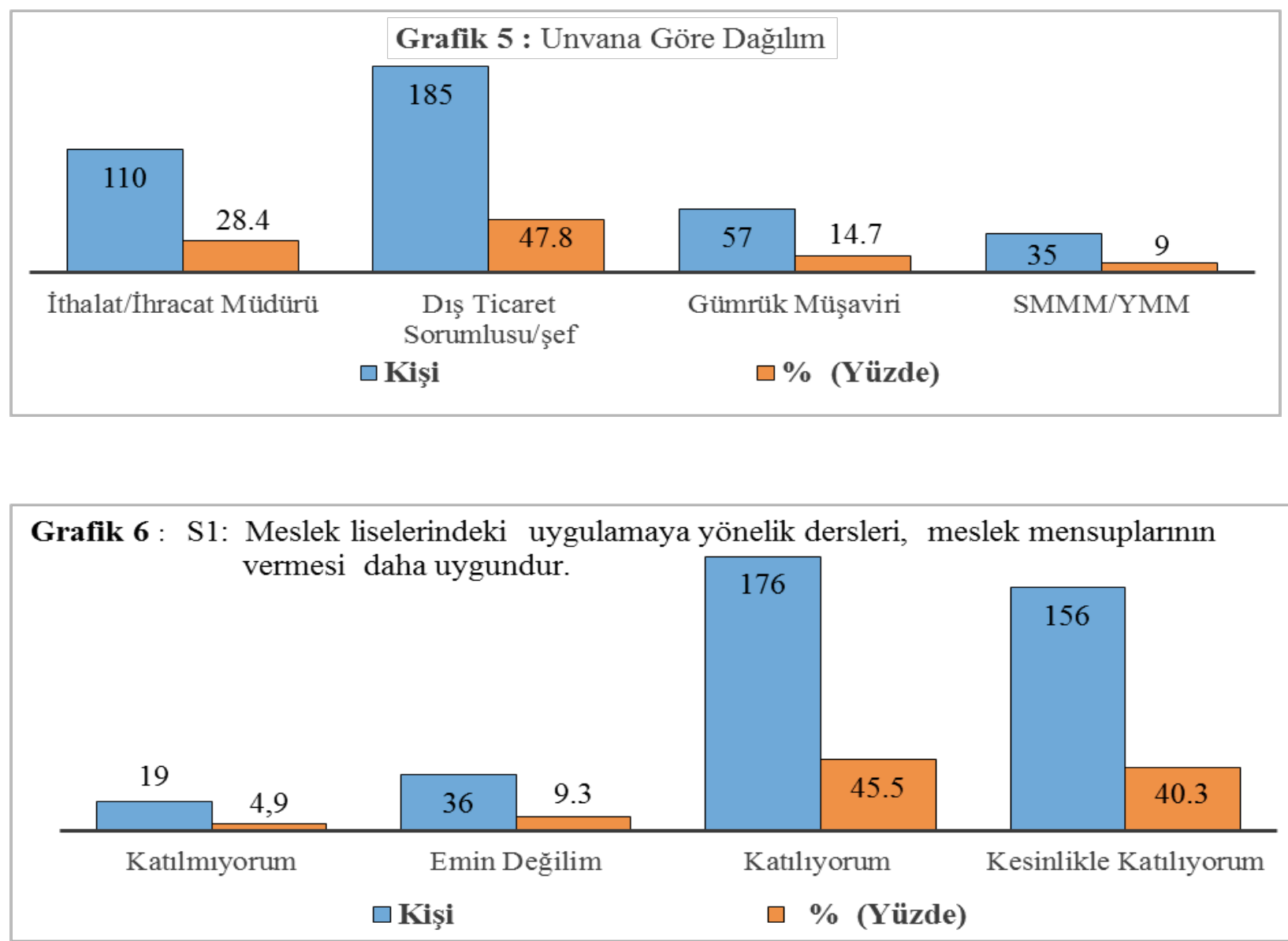

Grafik 7 : S2: Meslek lisesi öğrencilerine, meslek örgütleri tarafindan (Türmob, Gümr. müş.der.) diş ticaret ile ilgili seminerler verilmeli ve mesleğe adaptasyon sağlanmalıdır.

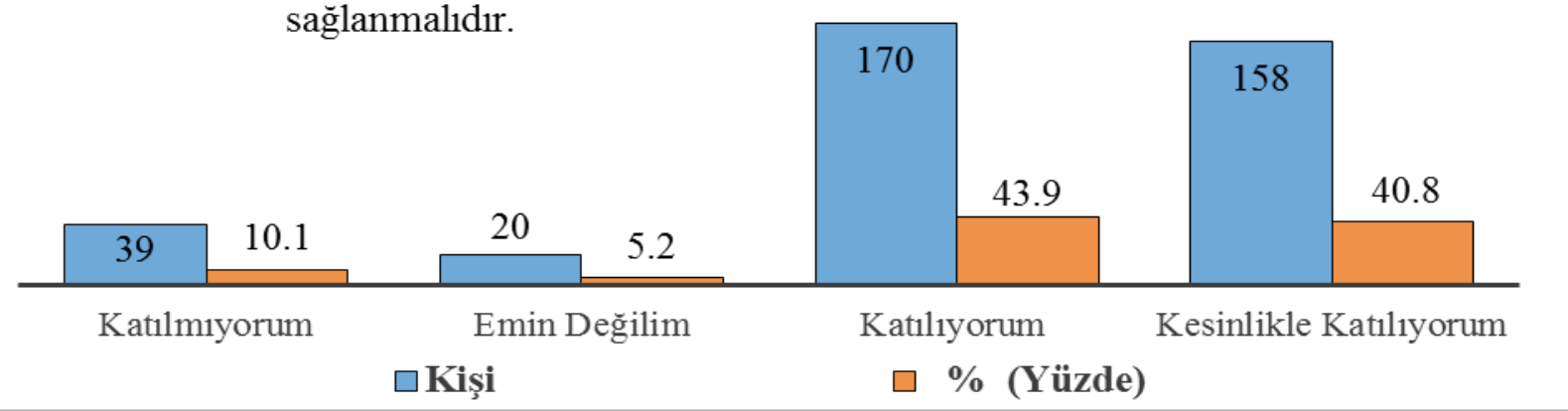

Grafik 8: $\quad$ S3: Meslek liselerinde verilen diş ticaret ofis eğitiminin denetimini meslek mensupları yapmalıdır.

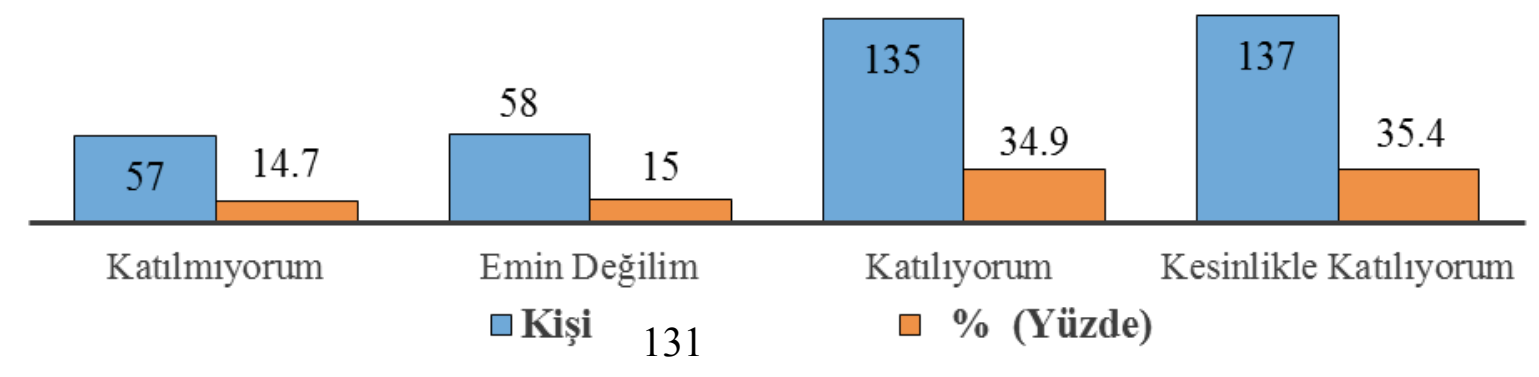



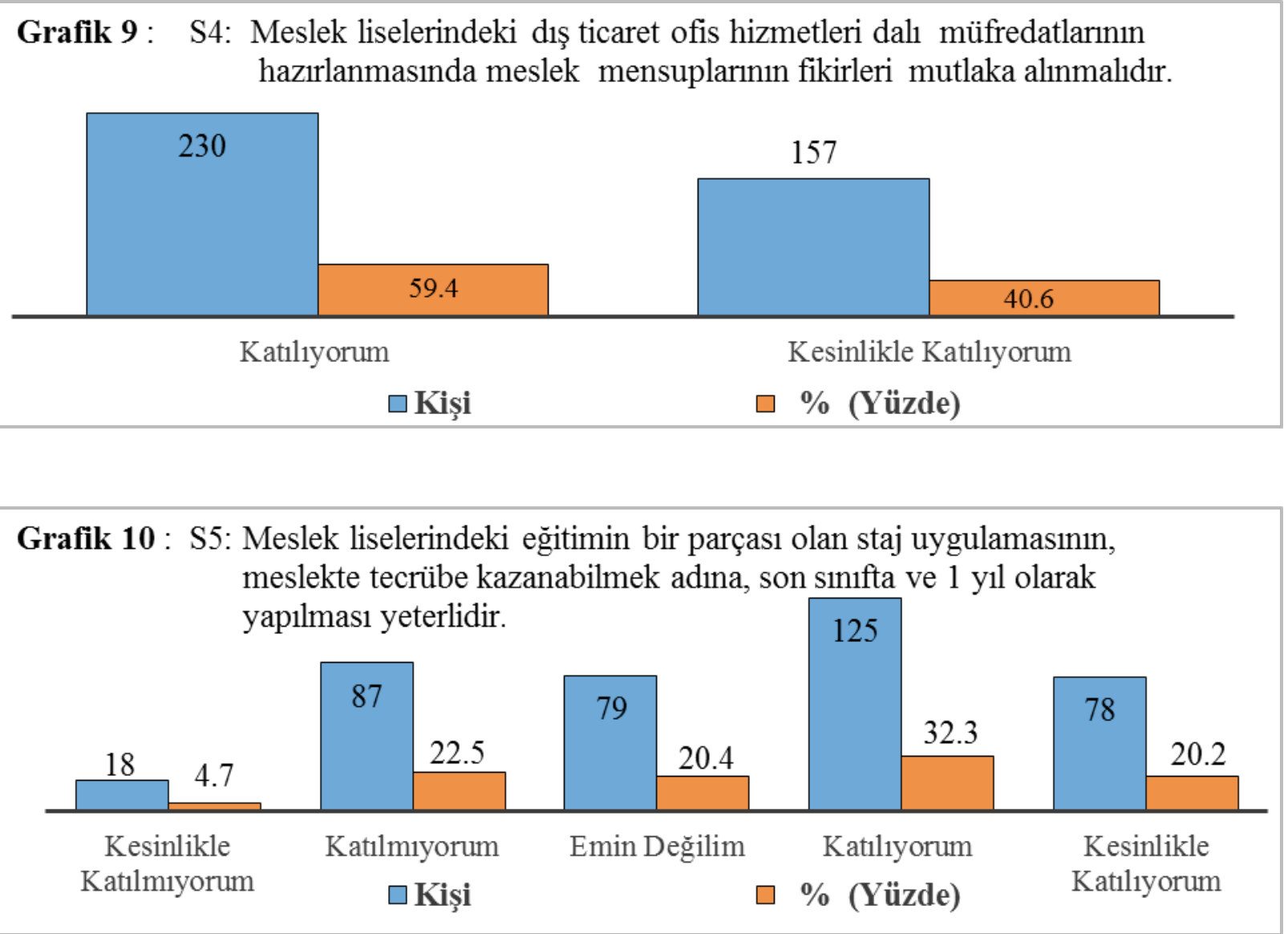

Grafik 11 : S6: Meslek liselerindeki öğretim programları, öğrencilerin staj yapacağı dış ticaret işletmelerinin uygulamaları ile örtüşür.

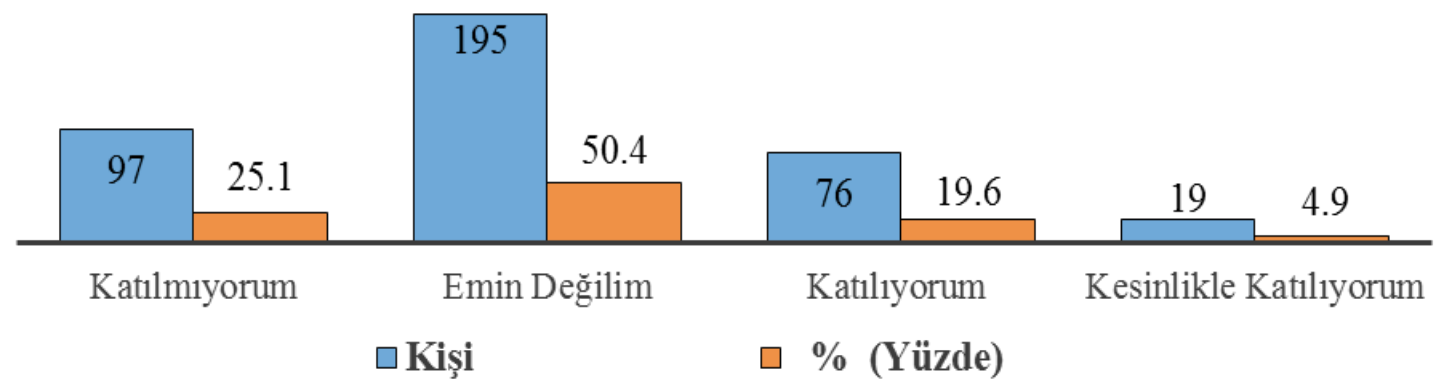


Grafik 12: S7: Meslek liselerinde diş ticaret ofis hizmetleri dalındaki öğrenciler,

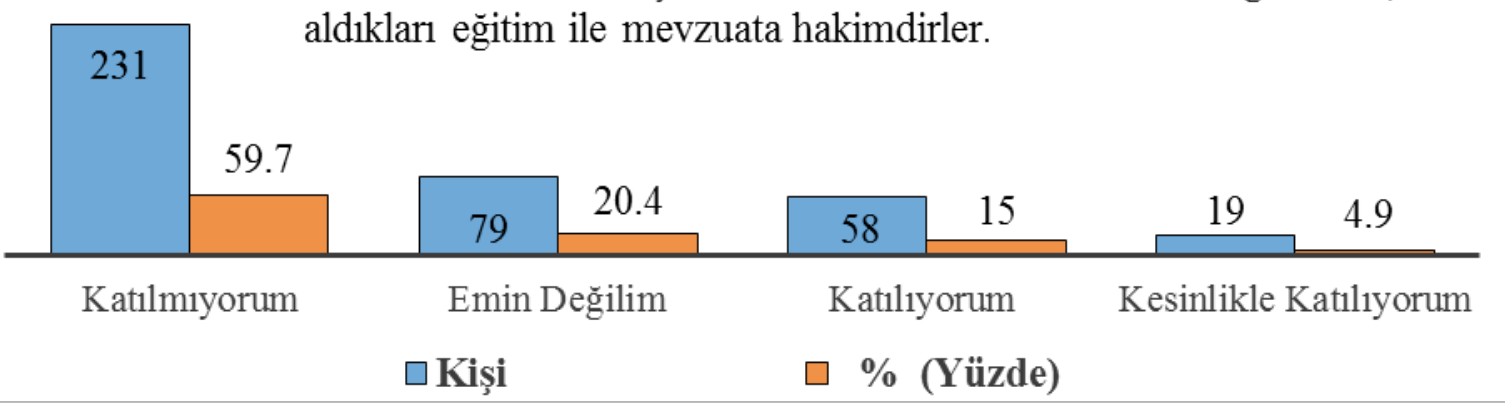

Grafik 13 : S8: Haftada üç gün olan staj çalışma günü artırılmalıdır.

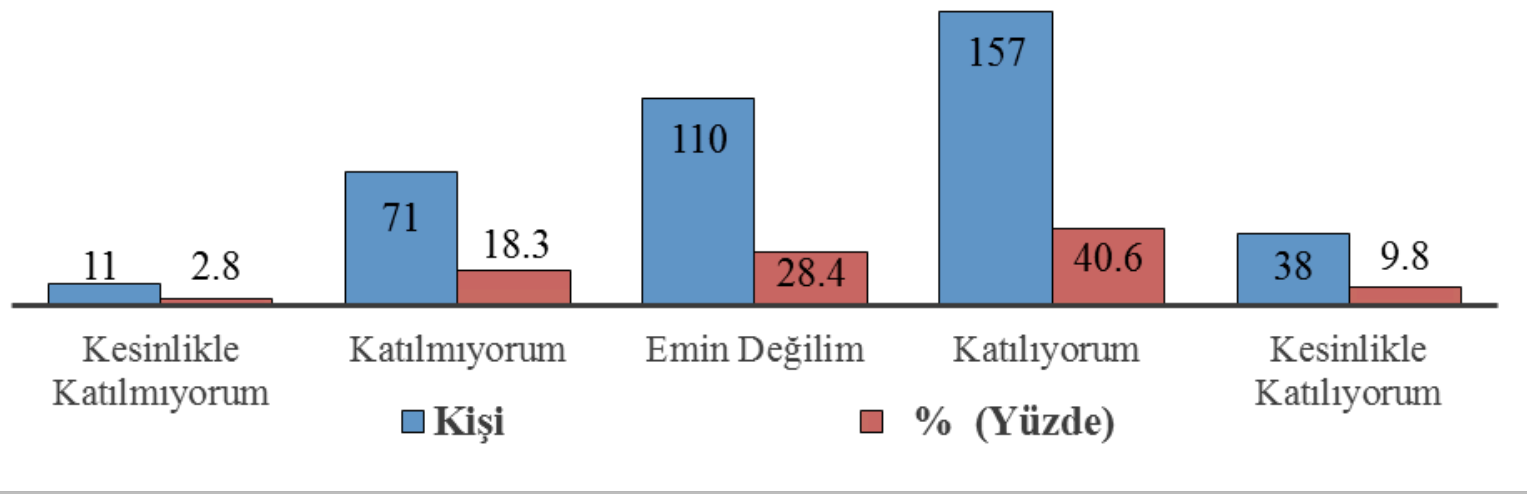

Grafik 14: S9 : Meslek liselerinde diş ticaret ofis hizmetleri dalındaki öğrenciler dış ticaret işlemleri dersinde okutulan ve diş ticarette kullanılan belgeleri düzenleyebilir.

\begin{tabular}{|c|c|c|c|c|c|c|c|}
\hline & \multicolumn{2}{|c|}{ belgeleri düzenleyebilir. } & & \multirow{2}{*}{139} & & 149 & \\
\hline 20 & 5.2 & 79 & 20.4 & & 35.9 & & 38.5 \\
\hline & $\begin{array}{l}\text { kle } \\
\text { orum }\end{array}$ & $\begin{array}{r}\text { Katı } \\
\square \text { Kiși }\end{array}$ & jorum & $\begin{array}{c}\text { Emir } \\
\square\end{array}$ & $\begin{array}{l}\text { ğilim } \\
\text { (Yüzde) }\end{array}$ & Katı & rum \\
\hline
\end{tabular}




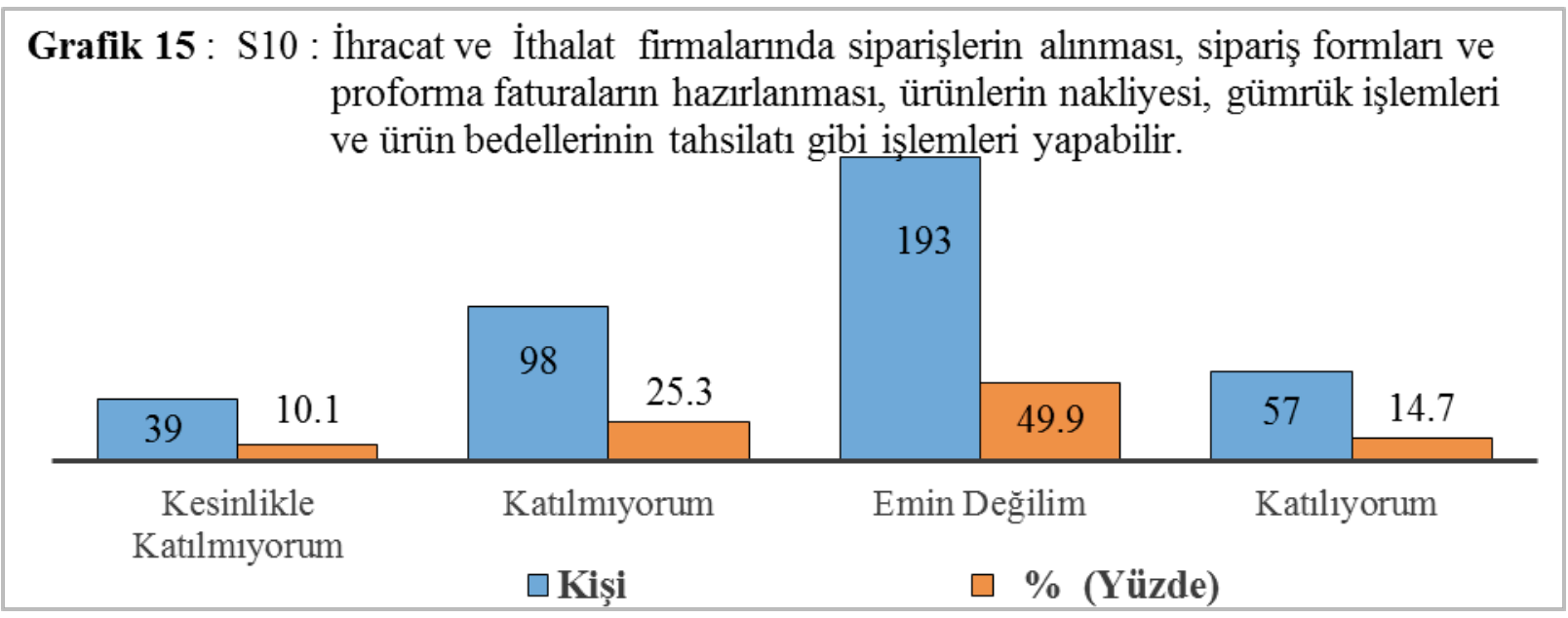

Grafik 16 : S11 : Diş ticaret ofis hizmetleri bölümlerinden mezun olan öğrenciler, öğretim süreci sırasında gördükleri kambiyo senetlerini (bono, poliçe ve çek) çalıştıkları işyerlerinde rahatlıkla düzenleyebilirler.

192

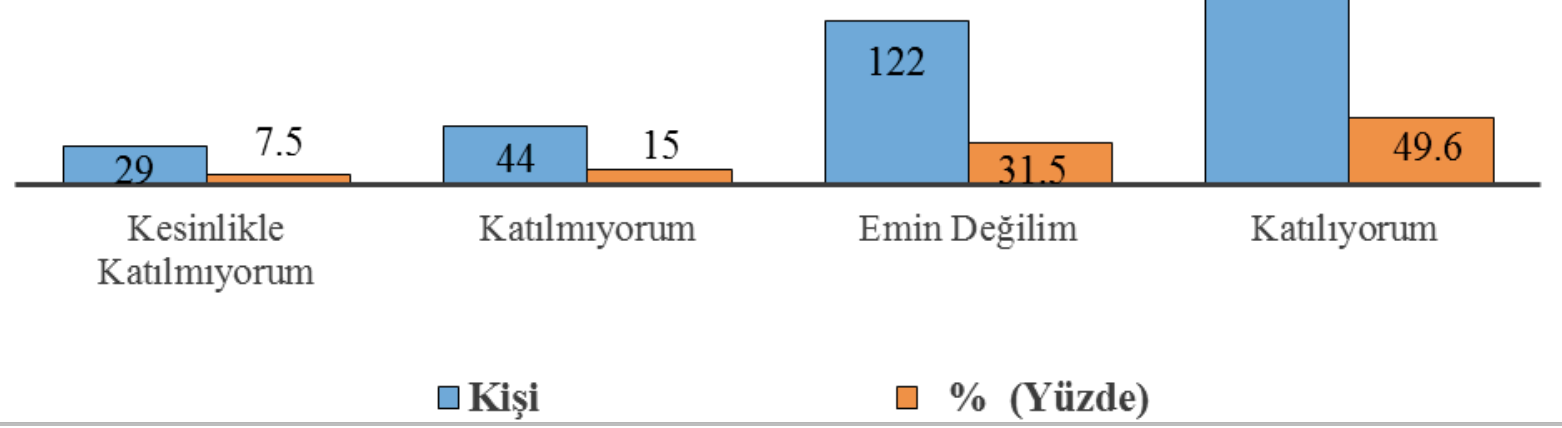

Grafik 17: S12 : Diş ticaret ofis hizmetleri alanından mezun olan öğrenci, diş ticarette teslim ve ödeme şekilleri işlemlerini yapabilir.

\begin{tabular}{|c|c|c|c|c|c|c|c|}
\hline & & & & 194 & & & \\
\hline 39 & 10.1 & 79 & 20.4 & & 50.1 & 75 & 19.4 \\
\hline Kesinlikle & 1lmiyorum & $\begin{array}{r}\text { Katıl } \\
\square \mathbf{K}\end{array}$ & yorum & Emin & $\begin{array}{l}\text { \%ğilim } \\
\text { \% }\end{array}$ & Kat & brum \\
\hline
\end{tabular}


Grafik 18 : S13 : D1ş ticaret ofis hizmetleri alanından alınan eğitim ile öğrenciler, herhangi bir diş ticaret firmasının ithalat ve ihracatına ilişkin, muhasebe işlemlerini ve kayıtlarını yapabilirler.

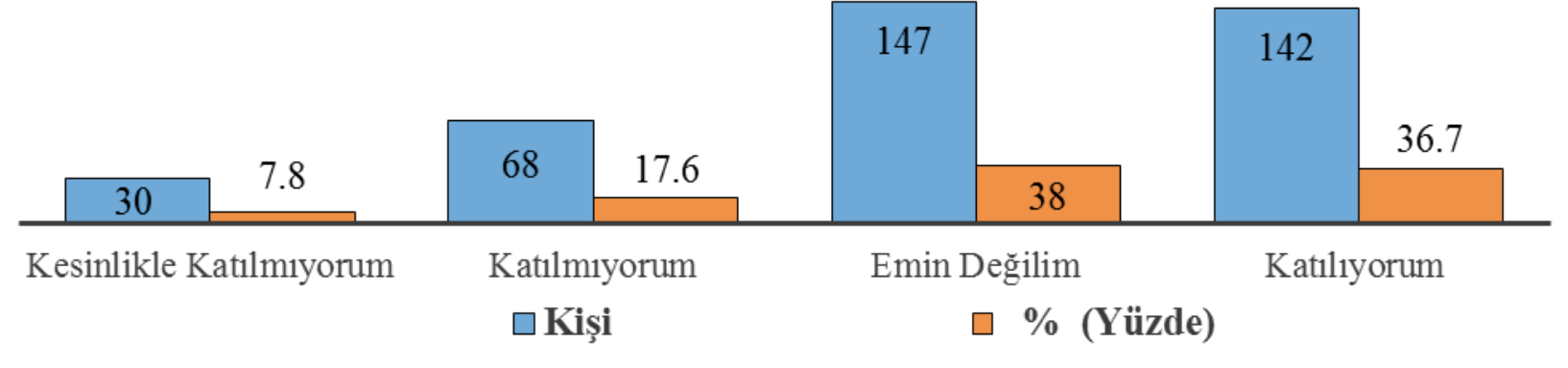

Grafik 19 : S14 : Diș ticaret ofis hizmetleri dalından mezun olan öğrenci, dış ticaret işletmelerini sinıflandırarak kullanılan belgeleri ilgili defterlere kaydedebilir.

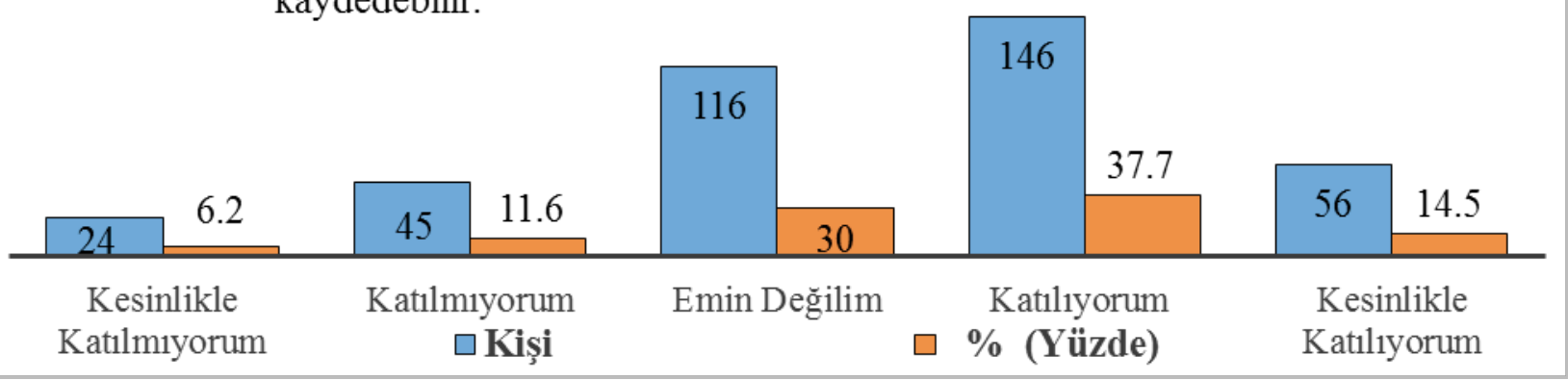

Grafik 20 : S15 : Meslek liselerinde verilen öğretim ile, öğrenciler şirket türleri ve özelliklerine göre muhasebe kayıtlarını yapabilirler

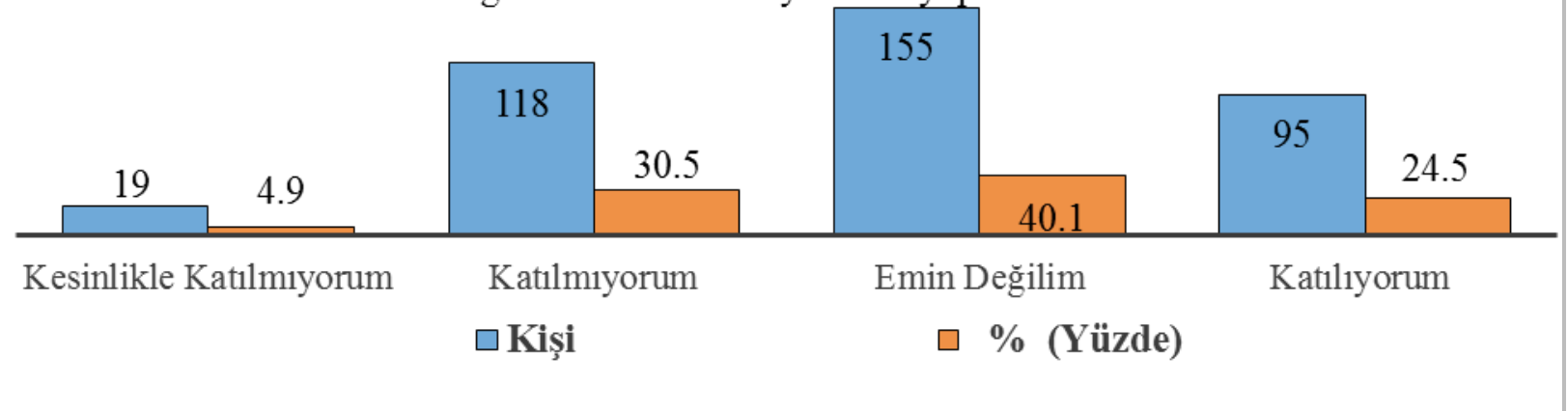


Grafik 21 : S16 : Meslek liselerinde okutulan Muhasebe I ve Muhasebe II derslerinde öğretilen bilgilerle öğrenciler işletmelere özgü ticari belgeleri, ticari defterleri ve beyannameleri, staj yerlerinde düzenleyebilir.
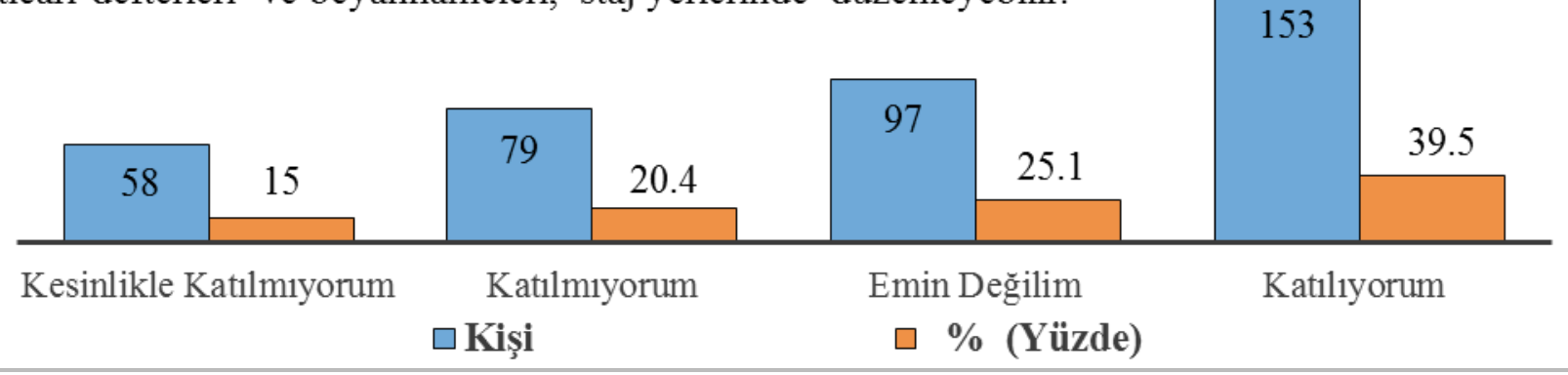

Grafik 22 : S17 : Meslek liselerinde herhangi bir bilgisayar programı öğrenen ögrenci, staj uygulamasinda farklı bir programa kolaylikla

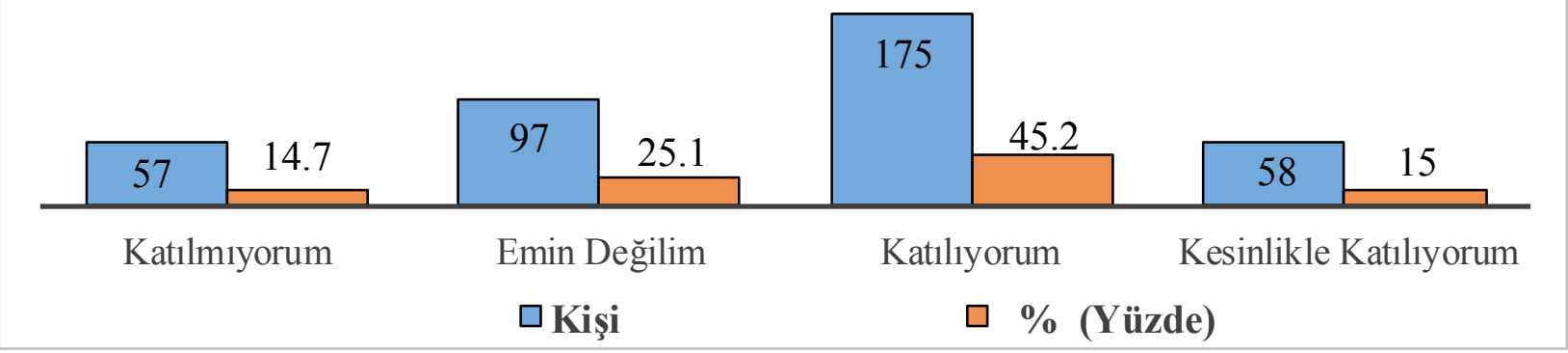

Grafik 23 : S18: Meslek lisesi öğrencileri, staj yaptıkları işyerlerinde, muhasebe işlerini, dış ticaret belgelerini bilgisayar kullanarak düzenleyebilir.

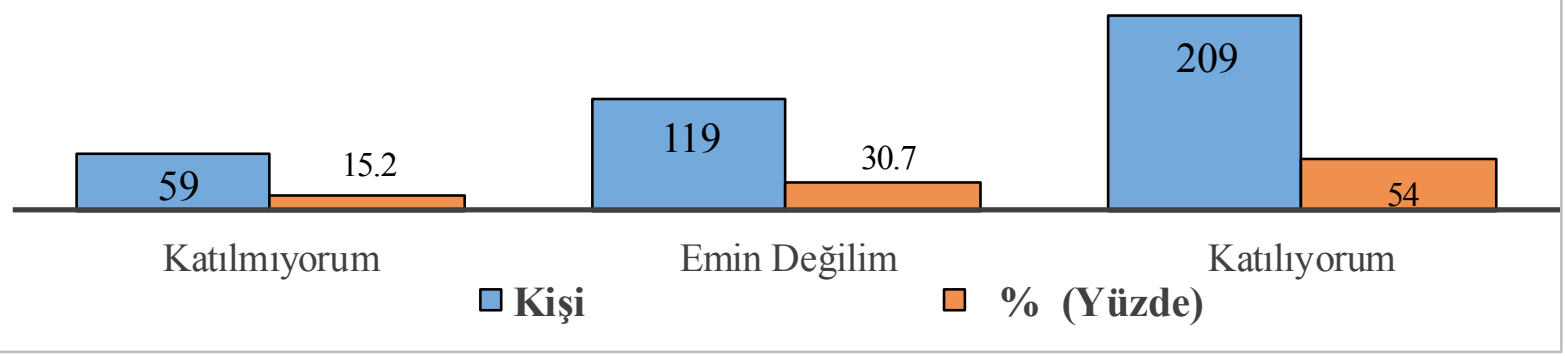


Grafik 24 : S19: Meslek liselerinde okutulan bilgisayarda ofis programları dersi ve bilgisayarda klavye dersleri dış ticaret işlerine uygundur.

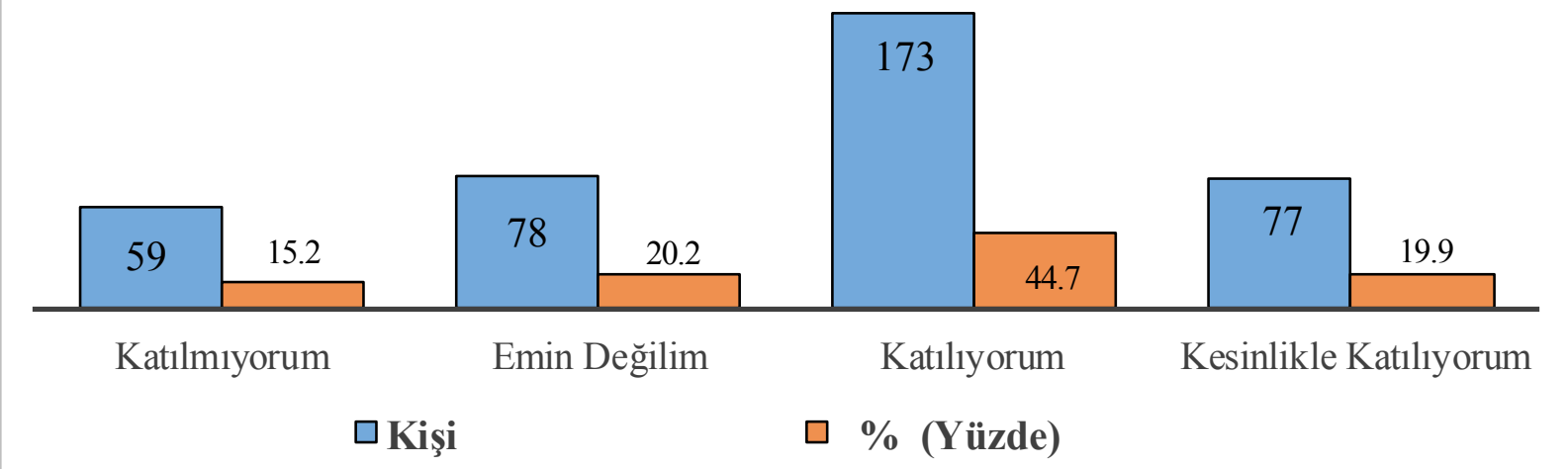

Grafik 25 : S20 : Dış ticaret ofis hizmetleri mezunları, kendi alanlarında iş bulma konusunda daha avantajlidırlar.

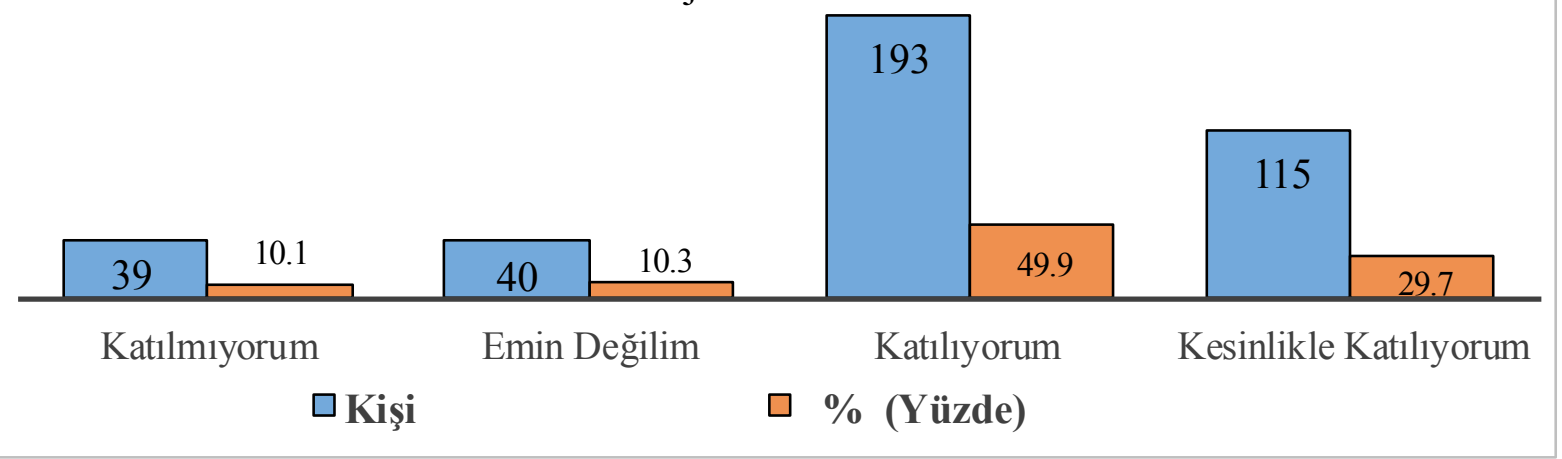


